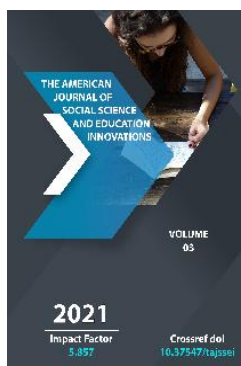

\title{
The Traditional Lexical Layer Of The Works Of Avaz Otar
}

\section{Sarvinoz Sharipova}

Master, Tashkent State University Of Uzbek Language And Literature Named After Alisher Navoi. Joint Department Of Turkology, Ahmad Yassavi International Turkish-Kazakh University, Uzbekistan

Journal Website:

http://theamericanjour

nals.com/index.php/taj

ssei

Copyright: Original content from this work may be used under the terms of the creative commons attributes 4.0 licence.

\section{ABSTRACT}

The article deals with the lexical features of Avaz Otar's works of the 19th century. Literary language and living colloquial words in the works are selected and analyzed. Special attention is paid to the ways in which words of different dialects enter the Uzbek literary language.

\section{KEYWORDS}

Sound, lexical layer, word and word form, dialect, literary language, colloquial language.

\section{INTRODUCTION}

Avaz Otar oglu, one of the prominent writers of Uzbek democratic literature, made a worthy contribution to the development of the Uzbek literary language with his works. Like all democratic poets and writers, Avaz
Otar oglu contributed to the development of the literary

language founded by the great Alisher Navoi, finding forms that meet the requirements of the time and its development. 
Avaz Otar tried to bring the modern language from the vernacular to the Uzbek literary language. For example, in his poems he used popular words such as dungeon, measure, rent, candle, hut. Proof of this can be seen in the following satirical quartet:

Sipohi poro istar,

Mulla ijora istar

Bechora chora istar,

Bir chora zamon bormu?

The features of the vernacular are also reflected in some morphological features, which are typical of the language of written works in the poems of Avaz Otar and the connective is almost never used. In his works, the form of the action name formed with the affix -v // uv // uv is noted. In this sense, his ghazal "Language" is characteristic::

Har tilni biluv emdi bani odama jondur

Til vositai robitan olamiyondur.

G'ayri tilini sa'y qiling bilgali, yoshlar,

Kim ilmu hunarlar rivoji andin ayondur.

Lozim siza har tilni biluv ona tilidek,

Bilmakka ani g‘ayrat eting, foydali kondur.

Ilmu fan uyiga yuboringlar bolangizni

Onda o'qug‘onlar sori yakton jahondur.

Zor o'Imasun onlar dog‘i til bilmay Avazdek,

Til bilmaganidin ani bag'ri to'la qondir.

The following are also typical of the vernacular: Avaz Otar:
1. It is known that in the old Uzbek literary language the pronoun I is stored in the 1st syllable ye. In Otar's poems, the vowel becomes the sound of a, which is characteristic of the spoken language (sheva):

Oh kim qildi falak, ayru diyorimdin mani

To yiroq solmoqqa bir gulrux nigorimdin mani.

Yoki:

Molimni yo'lida aylabon sarf,

Mandin hazar etgusi gadolar.

2. The Khorezmian dialect used the form of awakening instead of waking up:

Bu yanglig، olam ahlidin keyin qolmay yurush ayla,

Avaz, bo'lg‘ay uyonib komgoru komron millat.

The Navoi tradition in the language of Avaz Otar's works is as follows:

1. If Navoi created great works in the Uzbek literary language with his works and brought the Uzbek language closer to the vernacular, Avaz Otar oglu will continue this tradition. We have seen evidence of this in the above facts.

2. Uses many words and word forms used in Navoi's works:

a) The third person plural is also used in the form" alar":

Umidim-yashasin maktab bolasi,

Alar har biri sheri jayonim.

(«my devoted people»).

b) The conjuction -dag'i was also used. 
Ko'ngullarning sururi, dog'I ko'zlar nuridir farzand,

Alarning umrini, albatta obod etgusi maktab.

v)-used the affix gu // ku // gu // ku:

Bo'lg‘usi, ey dil, muyassar vasli jonon, g'am yema,

Kim oning kelmakligiga bordur imkon, g'am yema.

g) the form of the relative formed by the affix -bon // ibon // ubon is recorded:

Ochib har bir sarida maktabing unvonin aylabcho'x,

Taraqqiy aylamasmu o'qubon behaddu son millat.

d)The Navoi language also has a form in the use of the adjective of the future tense:

Ne manga yoron u hamdam, ne manga bir mehribon

Shum iqboli magardi (eyurdi), yo'ku borimdan meni.

e)The -a // e affix form of the route agreement is actively used:

Lozimsiza har tilni biluv ona tilidek.

j) The interrogative pronoun "Qaro" was used in Avaz Otar's poetry:

Qaro millatga bizdek gar nosimi inqiroz etsa

Anga albatta mustahkamlik ijod etgusi makteb.

3. As in the Navoi language, the languages of the Oghuz group (also because the
Khorezm dialect is the Oghuz group dialect) are influenced.

Masjidni o'ziga dom etibdur,

Bilmam, buni kim imom etibdur.

Some of the influences of "Shajarai Turk" and "Shajarai Tarokima" are also mentioned in Avaz Otar's poems. For example, the plural form of the third person pronoun is also used in the past tense:

Bilmayin onlarda hech millat, vatanni saqlamoq

Bo'Idi qurbon bu sabab din doimo ag‘yor xalq.

The vocabulary of Avaz Otar oglu's works consists mainly of Turkish and Arabic-Persian words. He hardly used words that came in through Russian and Russian.

In general, the works of democratic enlighteners such as Muqimiy, Furqat, Zavqiy, Avaz Otar ogli played a role in the rise of the Uzbek literary language in the second half of the XIX century..

\section{REFERENCES}

1. A. Mukhtorov, U. Sanakulov. History of Uzbek literary language. Tashkent: Teacher, 1995.

2. N. Rakhmonov, Q. Sodiqov. History of the Uzbek language. Tashkent: Publishing House of the National Society of Philosophers of Uzbekistan, 2009.

3. A. Aliyev, Q. Sodiqov. From the history of Uzbek literary language. Tashkent: Uzbekistan, 1994.

4. Ortikniyozovich, F. U. (2020). Theme: Forecasts And Results of The Negative Impact Of The Covid-19 (Coronavirus) 
The American Journal of Social Science and Education Innovations (ISSN - 2689-100x)

Published: May 31, 2021 | Pages: 442-445

Doi : https://doi.org/10.37547/tajssei/Volume03Issue05-78

2021: 5.857

Pandemic On The World Economy And The Economy of Uzbekistan. The American Journal of Interdisciplinary Innovations and Research, 2(08), 108-116.

5. Niyazova , G. .; Raupova , L. . Основные признаки и причины популярности детективного жанра. ОИ 2021, 2, 515-524. 